\title{
Footwear business of village owned enterprises (BUMDes) and its role in increasing rural economic activities
}

\author{
Ulul Hidayah*, Sri Mulatsih, and Yeti Lis Purnamadewi \\ Faculty of Economics and Management, Institut Pertanian Bogor, Indonesia \\ *Correspondence email: ulul_hidayah@apps.ipb.ac.id
}

\section{ARTICLE INFO}

- Research Article

Article History

Received 4 June 2020

Accepted 23 August 2020

Published 31 October 2020

\section{Keywords}

BUMDes; financial

feasibility; footwear; MSME; rural

JEL Classification L32; L60; R20

\begin{abstract}
The village owned enterprises (BUMDes) has an important role in stimulating rural development and therefore it is necessary to examine its feasibility as a profitable business venture and has a sustainable impact on village development. The purpose of this research is to conduct a feasibility analysis of the BUMDes and its role in developing rural economic activity. This research method used a financial feasibility analysis to BUMDes of Harapan Jaya in Bogor Regency, Indonesia. Data were obtained through focus group discussion with informants who work in BUMDes as operational manager, supervisors, commissioners, as well as village officials and MSME entrepreneurs. The results showed that business feasibility analysis in the footwear marketing business by BUMDes is feasible as indicated by the net present value of 318 million rupiah; benefit-cost ratio 1.026; internal rate of return 35\%; and a 2.56 year of payback period. Furthermore, BUMDes contributes significant profits for village. BUMDes involvement in the marketing of footwear products lead entrepreneurs and footwear workers earns a more income than the regional minimum wage. The collaboration between BUMDes and MSME resulted in a business profit of 80 million rupiah. BUMdes governance requires an increase in the quality of human resources and organization mechanism to be more competence and productive supporting performance targets, incentive mechanisms, and job satisfaction.
\end{abstract}

Citation: Hidayah, U., Mulatsih, S., \& Purnamadewi, Y. L. (2020). Footwear business of village owned enterprises (BUMDes) and its role in increasing rural economic activities. Journal of Socioeconomics and Development, 3(2), $134-144$. https://doi.org/10.31328/jsed.v3i2.1397

\section{INTRODUCTION}

Regional development aims to improve the quality and welfare of the community as measured by social, environmental, and economic aspects. From various factors of community welfare, economic development is one of the most important things in looking at people's welfare in an area. The rural development purposed to enhance the standard of living of rural communities and improving village welfare.

Rural economic growth is a process carried out by the community in managing existing resources in the village by forming partnerships, both with the government and with the private sector, which is characterized by the existence of a propulsive industry that can create new jobs and be able to stimulate an increase in the economy in the village (Asmawati \& Supriyono, 2014). The challenge in dealing with rural economic development is to strive for the sustainability of existing economic activities, especially in advanced rural areas with effective and efficient governance, the participation of all elements of village communities, the use of technology, the 
support of the business climate in production and marketing, security guarantees, providing added value, and employment.

Rural development is always faced with limited government budgets. This needs to be opened with the inclusion of private participation or local-based business entities to be involved in village economic development. This is expected to reduce the gap in urban and rural development, as well as to promote the spatial transformation of the village to a more developed direction. This effort is inevitable to drive investment growth, to change in space and location, develop transportation, to use natural resources, and to improve the quality of human resources (Yan \& Chen, 2018).

Law No. 6 of 2014 concerning Villages states that one of the priority programs in rural economic development is the establishment of village-owned enterprises (Badan Usaha Milik Desa, abbreviated as BUMDes). BUMDes is a business entity which is partly or wholly owned by the village through direct participation from the village wealth which is separated to manage assets, services, and other businesses for the maximum welfare of the village community (Regulation of the Minister of the Village, Development of Disadvantaged Areas, and Transmigration No. 4 of 2015 concerning Establishment, Administration, Management, and Closing of Village-Owned Enterprises). BUMDes aims at improving the village economy; optimizing village assets to be beneficial for village welfare; increasing community efforts in managing the economic potential of the village; developing business cooperation plans between villages and/or with third parties; creating market opportunities and networks that support general service needs; opening employment; improving community welfare through improving public services, growth and equitable distribution of the village economy; and increasing rural community income and village original income. BUMDes' management should prepare basic documents such as articles of association, bylaws, organizational administration, and financial administration (Kholmi, Jati, \& Suhardi, 2018).

Murwadji et al. (2017) argued that the management of BUMDes has two main obstacles namely performance and financial constraints. The obstacle to BUMDes' performance is the community's knowledge that is still limited in doing business professionally, especially in preparing financial reports and operating results. Meanwhile, financial barriers come from the fraud of funds management resulting from operations or acts of corruption. At present, many BUMDes are not well developed due to the lack of competence in implementing BUMDes management in terms of both knowledge and human resources (Gunaya, Sujana, \& Dewi, 2017; Muryanti, 2020). Suryanto (2018) stated that more than 22 thousand villages have already owned BUMDes, but those actively operating were less than $20 \%$. The various BUMDes activities have not yet shown significant changes to improve the local economy such as job opportunities and economic activities creation. The social system in the village is required to be reinforced to develop social entrepreneurship comprehensively through the active collaboration of village stakeholders and the community (Muryanti, 2020). This is also associated with inadequate development of BUMDes businesses due to the selection of business types that are not marketoriented, and are not based on a careful business feasibility study.

The feasibility study is an activity that assesses in-depth whether or not an activity or business to be carried out. The purpose of the feasibility study is to find out how to minimize impediments and risks to the future business development. BUMDes is a profit-oriented economic institution. It should be prudent in operating its business so that a basic consideration is needed from a business feasibility study to avoid the risk of bankruptcy. A feasibility study is used to evaluate whether or not a business is feasible at the beginning of starting a business, or in the context of expanding the development of an existing business (Aini \& Mawardi, 2019). The feasibility study is carried out so that the BUMDes can contribute sustainably to rural development, especially in the economic activity that affects the welfare of rural communities (Setyobakti, 2017).

Data from the Bogor Regency Community Empowerment Service in 2018 shows that out of a total of 416 villages in Bogor Regency, 380 of them already have BUMDes. However, only 79 villages are actively operating. One of the BUMDes that is active in Bogor Regency is BUMDes of Harapan Jaya, which is located in the village of Pagelaran. BUMDes of Harapan Jaya was founded in 2015, which was established as a mandate for the implementation of the village law. The development of the BUMDes in the last three years has not shown positive results. 
BUMDes is not yet optimal in absorbing labor and contributing to the village original income (Hidayah, Mulatsih, \& Purnamadewi, 2019b). The low performance of BUMDes is the result of determining the type of business that does not match the needs and potential of the village and has not carried out an in-depth business feasibility study. Moreover, BUMDes management and Village government officials have not been able to understand the business unit in detail. They also do not play a role in increasing village income and how to develop the economy of the village of Pagelaran.

This research aims to evaluate business feasibility and describe the role of BUMDes of Harapan Jaya in the economic development of Pagelaran Village.

\section{RESEARCH METHOD}

This research was conducted in Pagelaran Village, Ciomas District, Bogor Regency which was conducted from January to March 2019. The data used primary data from focus group discussion (FGD). The FGD was carried out with three BUMDes management elements including operational implementers (3 people), commissioners (2 people), and agency of regional consultative as supervisor (2 people). The FGD was conducted to determine the concept of the business to be run, as well as the business cost component, and to calculate business feasibility. The feasibility analysis of the BUMDes and Micro, Small, and Middle Enterprises (MSME) footwear business aims to determine whether the footwear business is feasible or not. The study assumed a discount rate of $5 \%$ per year. Four standard criteria are usually used in a business feasibility analysis, including net present value (NPV), benefit-cost ratio (BCR), payback period (PP), and internal rate of return (IRR).

NPV is the net present value which is the difference between the value of benefits and value of costs over the life of the investment. To illustrate the future cash value relative to the present, the value of costs and benefits is multiplied by the weighting factor (discount factor) (Fauzi, 2014). A business is said to be feasible or a profitable business investment if the NPV higher than 0 . In general, the NPV calculation is as follows.

$$
N P V=\sum_{t=1}^{n} \frac{\left(B_{t}-C_{t}\right)}{(1+i)^{t}}
$$

in which NPV is the net present value of the footwear business, Bt is benefits of the footwear business in the t-year, $\mathrm{Ct}$ is the cost of footwear business in the t-year, $i$ is interest rate, $t$ is the period in years $(1,2,3 \ldots \mathrm{n})$

Benefit-Cost Ratio (BCR) is a comparison of the cash value of project benefits with the cash value of project costs. A business is feasible to run if it has a $B C R$ value of more than 1 , if less than 1 , then the business is not feasible to run. In general, the BCR calculation is as follows:

$$
B C R=\frac{\sum_{t=1}^{n} B_{t} /(1+t)^{t}}{\sum_{t=1}^{n} C_{t} /(1+t)^{t}}
$$

BCR is the benefit-cost ratio of the footwear business, Bt is benefits of the footwear business in the $\mathrm{t}$-year, $\mathrm{Ct}$ is the cost of footwear business in the $\mathrm{t}$-year, $\mathrm{i}$ is interest rate, and $\mathrm{t}$ is the period in years $(1,2,3 \ldots \mathrm{n})$

Internal Rate of Return (IRR) is the value of the discount that makes the NPV of a zero-value business. IRR describes the maximum interest rate that can be paid for the utilization of resources by a business activity (Rustiadi, Saefulhakim, \& Panuyu, 2009). An effort is declared feasible if the IRR value is higher than of the interest rate, and vice versa. In general, the IRR calculation is as follows:

$$
I R R=i_{1}+\left(i_{2}-i_{1}\right) \frac{N P V_{1}}{\left(N P V_{1}-N P V_{2}\right)}
$$

IRR is internal rate of return of the footwear business, NPV1 is positive NPV, NPV2 is negative NPV, i1 is interest rate that produces a positive NPV, i2 is interest rate that produces a negative NPV.

Payback Period (PP) is a valuation technique to find out the period of return on investment of a business. In this study, the calculation of return on investment takes into account the discount factor and present value. A business is feasible if the PP value is lower than the life of the project, which means that after that period the company can return the capital spent on the business so it is feasible to run. In general, the PP calculation is as follows:

$$
\mathrm{PP}=\mathrm{n} \times(\mathrm{a}-\mathrm{b}) /(\mathrm{c}-\mathrm{b}) \times 1 \text { year }
$$

in which PP is payback period of the footwear business, $\mathrm{n}$ is the last year in that the amount of cash flow (incoming cash PV) still does not cover the initial investment, $a$ is the amount of initial investment, $b$ is cumulative amount of cash inflows in 
$\mathrm{n}$ year, and $\mathrm{c}$ is cumulative amount of cash inflows in year $n+1$.

Financial feasibility analysis conducted concerning on the following assumption: (i) the duration of project work is 8 years since the commencement of marketing in the first year, the project work time is derived from the economic life of the invested goods; (ii) stable marketing quantity, 150 scores per month; (iii) profits are obtained by BUMDes from the difference between the selling price of products to large companies and the purchase price of products from footwear entrepreneurs, namely five thousand rupiahs per pair, (iv) payment of salaries every 30 days, ( $v$ ) workers involved as many as 3 people, 2 people for administration and marketing, 1 person for distribution, (vi) the interest rate is $5 \%$; (vii) working day each year is 265 days.

\section{RESULT AND DISCUSSION}

\section{General Description of Pagelaran Village}

Pagelaran Village is located in the Ciomas District, Bogor Regency. Pagelaran Village has an area of 180 hectares, consisting of 16 community associations and 81 neighborhood associations. The total population of Pagelaran Village is 20.4 thousand people, consisting of 10.4 thousand men and 9.9 thousand women. The majority of its residents work in the footwear business activities. The development direction of the village refers to the vision and mission of development as outlined in the 2015-2020 Mid-Term Development Plan. The development plan document functions as a determinant of the direction of development in the village. The village's vision is to build a village towards progress. It is implemented in missions of improving infrastructure, developing the economy, increasing the economy of small businesses in footwear production, and increasing the skills of the villagers.

Table 1. Pagelaran Village Revenue, 2015-2018

\begin{tabular}{|c|c|c|c|}
\hline Revenue & 2015 & 2017 & 2018 \\
\hline & \multicolumn{3}{|c|}{........ million rupiahs ......... } \\
\hline Village fund & 307.5 & 867.7 & 769.2 \\
\hline Allocation of village fund & 513.6 & 516.6 & 526.2 \\
\hline $\begin{array}{l}\text { Regional levies and tax } \\
\text { revenue sharing }\end{array}$ & 170.2 & 299.0 & 343.8 \\
\hline Regent assistance & 200.0 & 100.0 & 200.0 \\
\hline Provin & 115.0 & 165.0 & 115.0 \\
\hline Original village exposure & 23.0 & 24.0 & 153.0 \\
\hline Financial assistance & 0.0 & 0.0 & 315.0 \\
\hline BUMDes equity participation & 0.0 & 0.0 & 50.0 \\
\hline
\end{tabular}

Source: Pagelaran Village (2019)

The village government of Pagelaran utilizes the development budget that is sourced from village funds, allocation of village funds, profit-sharing funds, and government assistance funds. Each year, the income budget received by Pagelaran Village increases. It can be seen in Table 1.

Pagelaran Village budget absorption can be categorized as quite good, with the realization of an average of $90 \%$ in 2018 (Table 2). The ability to manage the village fund allocation comes from the ability to access capital from other sources. The ability to find the potential of village resources can increase the village original income, as a capital factor that determines the readiness of the village government in implementing development (Wahyu, Aditya, Wardani, \& Jeni, 2019).

Table 2. Spending Budget of Pagelaran Village, 2015-2018

\begin{tabular}{|c|c|c|c|c|}
\hline Activity & 2015 & 2016 & 2017 & 2018 \\
\hline & \multicolumn{4}{|c|}{ } \\
\hline Government Administration & 386.4 & 482.6 & 561.3 & 686.7 \\
\hline Development Program & 1165.4 & 1317.2 & 1117.9 & 1182.2 \\
\hline Community Development & 19.8 & 141.9 & 184.4 & 181.0 \\
\hline Community Empowerment & 31.3 & 246.3 & 108.7 & 1977.4 \\
\hline
\end{tabular}

\section{The Economic Potential of Pagelaran Village}

Village-owned enterprises (BUMDes) are organizations formed by the village government and communities based on the mandate of Law Number 6 of 2014 concerning Villages. BUMDes has a role as a source of village income, to support village development programs and the implementation of village governance. The composition of the management of the BUMDes organization refers to the Regulation of the Minister of Village Development and Transmigration number 4 of 2015 concerning the Establishment, Administration, Management, and Closing of Village-Owned Enterprises. The management consists of advisors, operational 
executors, and supervisors. The BUMDes advisor is mandatory for the village head. Operational executors are held by villagers who are not concurrently village officials. Supervisors are selected from village consultative members. The management of the BUMDes of Harapan Jaya consists of a commissioner, a BUMDes chairman, two supervisors, a secretary, a treasurer, and six business unit heads (Figure 1).

The establishment of BUMDes of Harapan Jaya was approved on 19 June 2015. The BUMDes already has a set of articles of association and by laws stipulated by Pagelaran Village Regulation Number 2 of 2015. The statutes are legally strengthened by notarial deed No. 03 dated 23 March 2015. The establishment of BUMDes refers to the Pagelaran Village Regulation Number 1 of 2015 concerning the Establishment of a Pagelaran Village Owned Enterprise. In the recent condition, BUMDes business includes food and culinary, catfish cultivation, payment services, clean water facilities, and oyster mushroom cultivation.

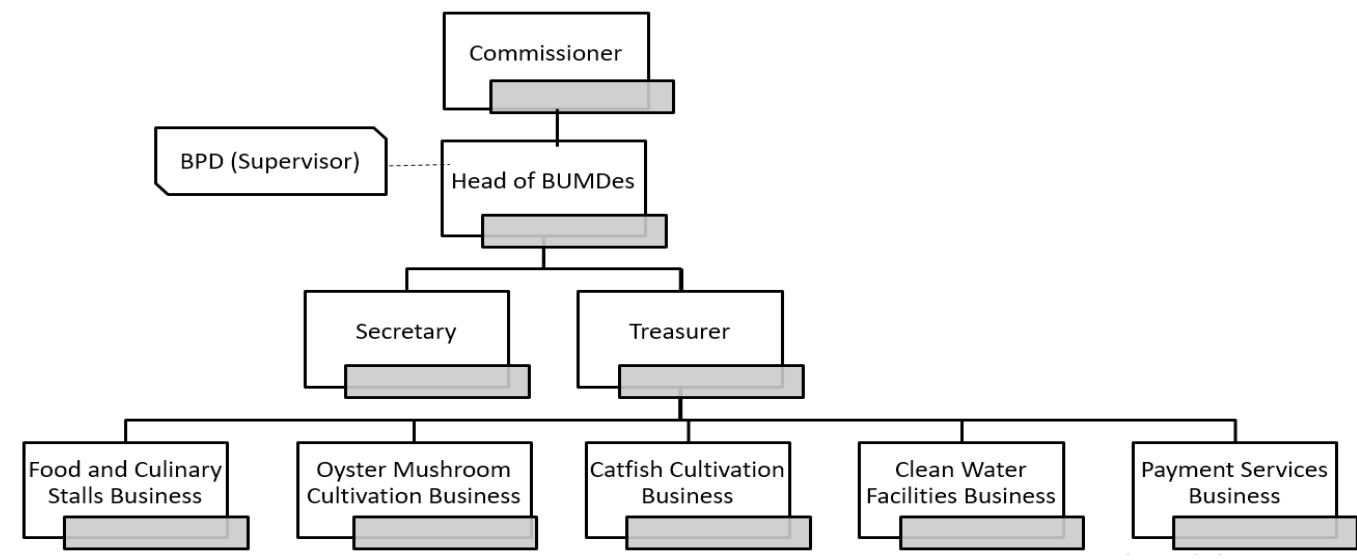

Figure 1. The organizational structure of BUMDes of Harapan Jaya. Source: Pagelaran Village (2019)

Entrepreneurship is an important key to generating economic growth. The types of entrepreneurship indicators affect gross domestic product (GDP) through various specific conditions. For example, entrepreneurial activity with indicators of business formation and need-based entrepreneurship could hurt growth in middle/low income countries. However, indicators of entrepreneurial attitudes such as perceptions, intentions, and role models have a positive influence on GDP in high-income countries (Doran, McCarthy, \& O'Connor, 2018). Micro, small and medium scale entrepreneurship also has an important role in rural economic development. However, the problem often arises in the development of entrepreneurship is the availability of funds. Ocasio (2016) shows that not all micro-loans have a positive effect on economic development. Awareness of the specific needs of borrowers is important in designing credit programs that will drive business growth.
Pagelaran Village is the center for MSME footwear products that have been marketed to various cities in Indonesia. A total of 89 businesses produce various types of footwear including baby shoes, children's shoes, adult shoes and sandals, army shoes, and others. The average footwear products are made to order from buyers. Certain shoe manufacturers produce shoes with a stock system. The reason is that the shoe model from the agent is no different from other types of footwear oriented to market trends.

The selling price of footwear products in the village varies greatly according to the model and quality of the product. Micro and small businesses generally sell footwear products with prices ranging from 400 to 600 thousand rupiahs per score. Meanwhile, medium-sized businesses sell products with prices above 600 thousand rupiahs per score. The selling price of products from the footwear business to the market is determined through 
negotiation agreements. From the average sales of micro-businesses, they gain monthly turnover is less than 50 million rupiahs. Meanwhile, the monthly turnover of small business range 50 to 100 million rupiahs and the medium-sized businesses receive more than 200 million rupiahs. Furthermore, the average income of micro and small businesses of less than 5 million rupiahs per month. The average income of medium-sized businesses is remarkably higher than 29 million rupiahs per month (Table 3).

Table 3. Selling Prices, Turnover, and Income of Footwear MSME

\begin{tabular}{|c|c|c|c|}
\hline \multirow{2}{*}{ Category of MSME } & \multicolumn{3}{|c|}{ Number of MSME } \\
\hline & Micro & Small & Medium \\
\hline & \multicolumn{3}{|c|}{.............. unit .............. } \\
\hline \multicolumn{4}{|l|}{ Selling Price } \\
\hline$<200$ thousand rupiahs/score & 2 & 2 & 0 \\
\hline $201-400$ thousand rupiahs/score & 1 & 14 & 0 \\
\hline $401-600$ thousand rupiahs/score & 3 & 15 & 0 \\
\hline$<600$ thousand rupiahs/score & 0 & 9 & 4 \\
\hline \multicolumn{4}{|l|}{ Average Turnover } \\
\hline$<50$ million rupiahs/month & 5 & 11 & 0 \\
\hline 51-100 million rupiahs/month & 1 & 25 & 0 \\
\hline 101-200 million rupiahs/month & 0 & 3 & 0 \\
\hline 201-300 million rupiahs/month & 0 & 1 & 2 \\
\hline >301 million rupiahs/month & 0 & 0 & 2 \\
\hline \multicolumn{4}{|l|}{ Average Income } \\
\hline$<5$ million rupiahs/month & 5 & 25 & 0 \\
\hline $5 \mathrm{~s} / \mathrm{d} 9$ million rupiahs/month & 1 & 12 & 0 \\
\hline 10 s/d 19 million rupiahs/month & 0 & 3 & 1 \\
\hline > 19 million rupiahs/month & 0 & 0 & 3 \\
\hline
\end{tabular}

Source: BUMDes "Harapan Jaya", data processed

The problem of developing MSME footwear business in Pagelaran Village is very diverse including variables of the availability of business capital, high raw material prices, decreasing labor force, dissatisfaction with selling prices, the role of craftsmen groups and the role of craftsmen and the government in business development (Hidayah, Mulatsih, \& Purnamadewi, 2019a). To be able to develop local potential, BUMDes of Harapan Jaya should form a new business unit for product marketing services. Although marketing efforts do not directly address the problems of MSME, it is closely related to the footwear business capital system, which has so far relied on wholesalers. With a new marketing service business, the BUMDes should also provide capital assistance so that the footwear business can produce higher.

The marketing business unit displays advantages because it is secure in terms of business risk, business capital, conformity to education needs and human resource skills, and is relevant to answering problems faced by MSME. The advantages of product marketing services are expected to immediately resolve cash management needs, generate business profits, and develop an extensive business (Hidayah, Mulatsih, \& Purnamadewi, 2020).

\section{BUMDes Business Model}

In the marketing of MSME footwear products in Pagelaran Village, BUMDes of Harapan Jaya can play a role in replacing the function of collecting traders (middlemen). As many as $83 \%$ of the footwear businesses in Pagelaran Village are small businesses. BUMDes focuses on empowering micro and small businesses so that their business operations can sustainably develop. Most of their business (92\%) has a target market for wholesale shops and the remaining $5 \%$ is marketed to large companies through wholesalers.

Small business operations with marketing to large companies generate greater profits even though it is carried out through middlemen. BUMDes can act as a marketing mediator for footwear products to large companies. BUMDes facilitates the footwear business, especially small businesses, to change the market segment from wholesale stores to large companies. Changes in market orientation demand an increase in the quality of footwear products, so BUMDes should cooperate with related agencies to improve business skills and control product quality.

BUMDes revenue in the footwear business is obtained from the profit of selling products. Based on the results of the FGD, BUMDes received a profit of five thousand rupiahs for each sale of a pair of footwear. During the FGD, four small entrepreneurs committed to supplying the BUMDes marketing business. They are ready to produce footwear with different types, namely women's flat shoes, women's sandals, men's sandals, and men's shoes. The sharing of venture capital between footwear entrepreneurs and BUMDes each contributed 50 percent.

The footwear business process starts with BUMDes of Harapan Jaya getting orders from large companies. BUMDes then forwards the order to footwear entrepreneurs. Footwear entrepreneurs will produce goods to order. The quality control process is carried out by BUMDes together with entrepreneurs to produce product quality standards. Furthermore, the products are distributed by BUMDes 
to large companies. Three days after the delivery of the goods, BUMDes will get the proceeds from the sale which are then partially paid to the footwear entrepreneur. The flow of BUMDes footwear marketing business activities is presented in Figure 2 .

BUMDes assists entrepreneurs to increase innovation in making footwear products. Joint monitoring and evaluation between BUMDes management and entrepreneurs is carried out every 3 months while updating market demand information. BUMDes also creates a catalog of footwear products to meet market demand. The collaboration between BUMDes and MSME footwear business shows the strength of economic activity through a sustainable supply chain. This work is not simple to achieve but requires the readiness of village resources to maintain sustainability. Villages need to prepare with adequate human resources in making village regulations, looking for business opportunities, preparing managers, making reports, and implementing supply chain management (Sulastriyono \& Saputra, 2020).

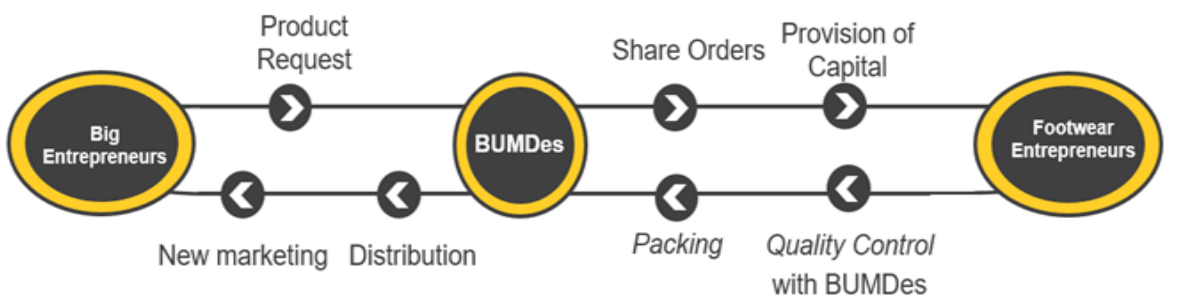

Figure 2. Footwear marketing business activities by BUMDes

\section{Business Feasibility}

The business feasibility analysis was conducted to know the feasibility of establishing a footwear marketing business. There are several important cost components in the establishment of this business, namely revenue, investment costs, and operational costs.

Table 4. Annual Revenue of BUMDes Footwear Marketing Business

\begin{tabular}{lccc}
\hline Sale of product & $\begin{array}{c}\text { Number } \\
\text { of Goods }\end{array}$ & $\begin{array}{c}\text { Cost per } \\
\text { Unit }\end{array}$ & Total Cost \\
\hline thousand & $\begin{array}{c}\text { thousand } \\
\text { pair }\end{array}$ & $\begin{array}{c}\text { million } \\
\text { rupiahs } \\
\text { rupiahs }\end{array}$ \\
Women's flat shoes & 15 & 50 & 750 \\
Wedges women's sandals & 9 & 60 & 540 \\
Men's sandals & 6 & 50 & 300 \\
Men's shoes & 6 & 55 & 330 \\
Total & & & 1,920 \\
\hline
\end{tabular}

Source: BUMDes "Harapan Jaya", data processed

The revenue from the marketing of footwear products by BUMDes comes from the number of sales. The level of product sales is determined based on capital capability and consumer demand. Distribution is carried out directly from the MSME to the warehouse by the BUMDes. The total annual revenue of the marketing business of BUMDes is 1.920 billion rupiahs (Table 4).

The investment needs in the footwear marketing business are used to procure vehicles for distribution, computers, and supporting equipment. The total investment cost is approximately 214.5 million rupiahs in a year (Table 5).

Table 5. Annual Investment Needs of BUMDes Footwear Marketing Business

\begin{tabular}{lc}
\hline Goods & Total Cost \\
\hline & million rupiah \\
Computer & 10.0 \\
Modem & 1.0 \\
Printer & 2.0 \\
Pick-up vehicle & 200.0 \\
Desks & 1.5 \\
Total & 214.5 \\
\hline Source: BUMDes "Harapan Jaya", data processed
\end{tabular}

Costs required in a footwear marketing business consist of fixed costs and variable costs. It is estimated that the total cost required is 1.839 billion rupiahs. Fixed costs are costs whose amounts are not affected by the development of production and sales. Meanwhile, variable costs are costs incurred by the development of production (Nurmalina, Sarianti, \& 
Karyadi, 2014). The fixed and variable costs used in conducting business can be seen in Tables 6 and 7 .

Table 6. Annual Fixed Costs of BUMDes The Footwear Marketing Business

\begin{tabular}{lcc}
\hline Fixed Costs & $\begin{array}{c}\text { Cost per } \\
\text { month }\end{array}$ & Cost per year \\
\hline Communication & $\ldots .$. thousand rupiahs... \\
Stationary & 100 & 1,200 \\
Transportation & 100 & 1,200 \\
Electricity & 500 & 6,000 \\
Labor cost (2 person) & 50 & 600 \\
Vehicle tax & 5,000 & 60,000 \\
Total & - & 6,000 \\
Source: BUMDes "Harapan laya", data processed
\end{tabular}

Table 7. Annual Variable Costs of BUMDes Footwear Marketing Business

\begin{tabular}{lccc}
\hline Costs of product & Number of & Cost per & Total \\
& Goods & Unit & Cost \\
\hline Women's flat shoes & pair & .. & million rupiahs... \\
Wedges women's sandals & 15000 & 45 & 675 \\
Men's slippers & 9000 & 55 & 495 \\
Men's shoes & 6000 & 45 & 270 \\
Labor cost (1 person) & 6000 & 50 & 300 \\
Total & - & 2 & 24 \\
Source: BUMDes "Harapan Jaya", data processed & \multicolumn{4}{l}{, 764} \\
\hline
\end{tabular}

The analysis of business feasibility criteria is carried out to determine whether the footwear marketing business unit by BUMDes is feasible or not. The calculation of investment criteria uses the cash flow method, where business projection over the next ten years is discounted at present. The analysis of the feasibility criteria can be seen in Table 8.

Table 8. Feasibility Criteria of BUMDes Footwear Marketing Business

\begin{tabular}{lc}
\hline Value Investment & Criteria \\
\hline NPV (million rp) & 318.2 \\
Net B/C & 1.026 \\
IRR (\%) & 35.0 \\
Payback Period (years) & 2.56 \\
\hline
\end{tabular}

Source: BUMDes "Harapan Jaya", data processed

The results of the calculation obtained an NPV of Rp. 318.2 million rupiahs. This value indicates that the business inflow for 8 years with an interest rate of 5 percent is greater than the cash outflow. These results indicate that the footwear marketing business by BUMDes is profitable and feasible to be implemented in the long term $(\mathrm{NPV}>0)$. The $\mathrm{B} / \mathrm{C}$ ratio value in the footwear marketing business is 1.026. This value indicates that for every 1 expense incurred will result in a benefit of Rp. 1.026. This criterion also shows that the BUMDes business meets feasibility.

This study resulted in an IRR value of $35 \%$. This indicates that the footwear marketing business has a projected return on investment of $35 \%$. This also shows that the ability to return the capital is greater than the discount rate so that the business is feasible to develop. IRR shows the project's ability to generate a level of return on capital for companies that invest during the project implemented. The results of the analysis of the return on investment based on the present value with a discount rate of 5 percent, found the payback period of 2 years and 5.6 months. The magnitude of time is shorter than the calculation of the project life. This means that after that period, the BUMDes can return the capital that was spent, and the business of marketing footwear products began to earn profits.

Based on the analysis of the eligibility criteria, BUMDes of Harapan Jaya generally can revitalize its business by forming a new footwear marketing business unit in collaboration with local MSME. The synergy through the joint marketing system prevents negative market competition. Joint marketing is expected to provide advantages for small businesses because the selling price of the product has been agreed on by BUMDes. The collaboration also creates faith in price stability, enables to prepare business plans, and creates a conducive business environment for village development (Sutrisno, 2019). The collaboration can also be purposed to maintain production stability to prevent markedly changes in sales prices and market situations (Puspitaningrum \& Gayatri, 2019). Meanwhile, this study shows that BUMDes can receive profits of 80 million rupiahs per year. The profit of the BUMDes business can provide the contribution potential of income to the village of Pagelaran. It is approximately four million rupiahs per year for supporting the village development program. This can further create independence for the village government to manage community services and village development.

The great potential of BUMDes management should be balanced with adequate public accountability. It is necessary to optimize the responsibility mechanism that is carried out both vertically and horizontally. An accountability 
mechanism based on governance is needed where stakeholders interact with each other to influence public policy outcomes. They interact with each other in the management of public organizations to meet the needs of the community. Because the central role of the village head in the BUMDes management process, it will likely create a conflict of interest in maintaining accountability in the management of the BUMDes (Kurniasih, Wijaya, \& Setyoko, 2019). BUMDes governance is required to implement the principles of corporate governance and accountability that refer to village financial management. Thus, it can reduce the circumstance of abuse of authority or corrupt behavior (Winarsi, Widyantoro, \& Moechthar, 2018).

The success of the collaboration in the marketing of footwear between the MSME and BUMDes is influenced by two factors. First is human resources. Qualified human resources are needed to drive BUMDes performance. Sofyani, Atmaja, \& Rezk (2019) stated that the factors that drive BUMDes performance are patriotism, enthusiasm, skills, education level, experience, honesty, sense of responsibility, sincerity, seriousness, concern for the environment and society. Second is the organizational mechanism. BUMDes management should be taken along to an organizational mechanism that is conducive to improve performance and productivity. The organization encourages teamwork, participation and good communication, and transparency of management responsibilities. The organization facilitates the working of visionary leadership, the achievement of performance targets, incentive mechanisms, and job satisfaction. The rural business development program should be emphasized on implementing functions of organization mechanism such as developing innovation, making economic partnerships, strengthening capital formation, applying positive values of all members, facilitating members into the agribusiness chain, and improving the cluster of the production system (Soetriono, Soejono, Zahrosa, Maharani, \& Hanafie, 2019). It also requires supporting factors in terms of infrastructure and facilities, the technology of processing equipment, and processed product modification technology (Rahim, 2018)

For micro and small entrepreneurs, partnerships with BUMDes essentially do not change the market segment. Even if there is a change, it will happen gradually and produce positive mechanisms for MSME. Micro and small entrepreneurs can still produce footwear to sell to grocery stores whenever they want, without disrupting cooperation with BUMDes. Furthermore, the footwear marketing business activities by BUMDes can improve the welfare of entrepreneurs and footwear business workers. They even earn more income than the regional minimum wage in Bogor Regency area.

\section{CONCLUSION AND SUGGESTION}

The financial analysis of the BUMDes footwear marketing business in collaboration with MSME shows business feasibility. The feasibility criteria for the footwear marketing business resulted in a net present value of 318.2 million rupiahs, a benefit-cost ratio of 1.026 , and internal rate of return of $35 \%$ (more than a $5 \%$ discount rate), and a payback period of 2.56 years. The collaboration between BUMDes and MSME resulted in a business profit of 80 million rupiahs. The collaboration also contributes income to the village income of four million rupiahs per year to support the village development program. This can build independence to manage government services and village development.

The synergy through the joint marketing system prevents negative market competition. The collaboration also does not prevent micro and small entrepreneurs from producing and selling footwear to grocery stores whenever they want without disturbing the product supply for BUMDes. The collaboration also resulted in increased income for entrepreneurs and workers in the footwear business, which exceeded the regional minimum wages in the Bogor Regency.

BUMDes governance requires an increase in the quality of human resources to be more competitive and productive. BUMDes organizations are also encouraged to be able to facilitate the working of visionary leadership, performance targets, incentive mechanisms, and job satisfaction.

\section{REFERENCES}

Aini, Q., \& Mawardi, M. (2019). Analisis kajian kelayakan usaha BumDes "Beriuk Berkarya" Desa Lando unit usaha sistem penyediaan air minum desa serta perannya dalam peningkatan Pendapatan Asli Desa tahun 2018/2019. JPEK (Jurnal Pendidikan Ekonomi Dan Kewirausahaan), 
3(1),

https://doi.org/10.29408/jpek.v3i1.1388

Asmawati, T., \& Supriyono. (2014). Pemberdayaan Usaha Mikro, Kecil, dan Menengah sebagai upaya peningkatan pertumbuhan ekonomi perdesaan di masyarakat Kecamatan Manyaran Kabupaten Wonogiri. In Seminar Nasional Pendidikan Akuntansi dan Keuangan "Pengembangan Pendidikan Akuntansi dan Keuangan yang Berkelanjutan" (pp. 254-269). Solo: Universitas Sebelas https://doi.org/10.23917/jpis.v29i1.8241

Doran, J., McCarthy, N., \& O'Connor, M. (2018). The role of entrepreneurship in stimulating economic growth in developed and developing countries. Cogent Economics and Finance, 6(1), 1-14. https://doi.org/10.1080/23322039.2018.1442093

Fauzi, A. (2014). Valuasi Ekonomi Dan Penilaian Kerusakan Sumber Daya Alam Dan Lingkungan. Bogor: IPB Press. Retrieved from https://onesearch.id/Record/IOS5876.INLIS00000 0000017096

Gunaya, G., Sujana, E., \& Dewi, P. (2017). Fenomena rankap jabatan dalam pengelolaan keuangan badan usaha milik desa (BUMDes): studi kasus pada Badan Usaha Milik Desa Mandala Parahita Desa Tinggarsari, Kecamatan Busungbiu, Kabupaten Buleleng. E-Jurnal Akuntansi, 18(2), $1-12$.

https://doi.org/http://dx.doi.org/10.23887/jimat.v $8 \mathrm{i} 2.13929$

Hidayah, U., Mulatsih, S., \& Purnamadewi, Y. L. (2019a). Analisis kinerja dan strategi pengembangan UMKM alas kaki di Desa Pagelaran. Jurnal Benefita, 4(3), 435-448. https://doi.org/10.22216/jbe.v4i3.4232

Hidayah, U., Mulatsih, S., \& Purnamadewi, Y. L. (2019b). Evaluasi Badan Usaha Milik Desa (BUMDes): Studi kasus BUMDes Harapan Jaya Desa Pagelaran, Kecamatan Ciomas, Kabupaten Bogor. Jurnal Sosial Humaniora Dan Pendidikan, $3(2)$, 144-153. https://doi.org/https://doi.org/10.32487/jshp.v3i2 .676

Hidayah, U., Mulatsih, S., \& Purnamadewi, Y. L. (2020). Optimalisasi unit usaha BUMDes Harapan Jaya berdasarkan potensi lokal di Desa Pagelaran. Jurnal Benefita, 5(1), 101-112. https://doi.org/10.22216/jbe.v5i1.4274

Kholmi, M., Jati, A. W., \& Suhardi, D. (2018). Management of private enterprises as an accomplishment of the independence economic village. Jurnal Ekonomi Pembangunan Volume,
16(2),

https://doi.org/10.22219/jep.v16i2.9053

83-92.

Kurniasih, D., Wijaya, S. S., \& Setyoko, P. I. (2019). Public governance in accountability of village enterprise (BUMDes) management: a stakeholders perspective. IAPA Proceedings Conference, 180. https://doi.org/10.30589/proceedings.2018.192

Murwadji, T., Rahardjo, D. S., \& Hasna. (2017). BUMDes sebagai badan hukum alternatif dalam pengembangan perkoperasian Indonesia. ACTA DIURNAL Jurnal Ilmu Hukum Kenotaraiatan, 1(1), 1-18. Retrieved from http://jurnal.fh.unpad.ac.id/index.php/acta/article /view/154

Muryanti, M. (2020). Towards social entrepreneurship in the village through village-owned enterprises. Society, 8(1), 163-174. https://doi.org/10.33019/society.v8i1.161

Nurmalina, R., Sarianti, T., \& Karyadi, A. (2014). Studi Kelayakan Bisnis. Bogor: IPB Press. Retrieved from https://opac.perpusnas.go.id/DetailOpac.aspx?id $=995183$

Ocasio, V. M. (2016). Financing village enterprises in rural Bangladesh: what determines non-farm revenue growth? International Journal of Development Issues, 15(1), 76-94. https://doi.org/10.1108/IJDI-09-2015-0057

Pagelaran Village. 2019. Profile of Pagelaran Village, Ciomals District, Bogor Regency. Unpublished document.

Puspitaningrum, D. A., \& Gayatri, S. (2019). Farm partnership between farmers and the company in production and marketing of vegetables commodity. Journal of Socioeconomics and Development, 2(1), 45-53. https://doi.org/10.31328/jsed.v2i1.975

Rahim, A. (2018). The Empowerment strategy of the traditional fisherman's wives in the coastal area of Barru Regency, South Sulawesi. Journal of Socioeconomics and Development, 1(1), 1-6. https://doi.org/10.31328/jsed.v1i1.515

Rustiadi, E., Saefulhakim, S., \& Panuyu, D. R. (2009). Perencanaan dan Pengembangan Wilayah. Jakarta: Yayasan Pustaka Obor Indonesia. https://books.google.co.id/books?id=dfZiDwAAQB AJ

Setyobakti, M. H. (2017). Identification of business enterprises BUMDes based on social aspect: Case study at BUMDes Ijen Lestari Tamansari Village, District of Banyuwangi. Jurnal Ilmiah Bidang 
Akuntansi Dan Manajemen (JEMA), 14(2), 101110. https://doi.org/10.31106/jema.v14i02.592

Soetriono, S., Soejono, D., Zahrosa, D. B., Maharani, A. D., \& Hanafie, S. R. (2019). Strategy and policy for strengthening the agricultural cooperative business in East Java, Indonesia. Journal of Socioeconomics and Development, 2(1), $12-22$. https://doi.org/10.31328/jsed.v2i1.886

Sofyani, H., Atmaja, R., \& Rezki, S. B. (2019). Success factors of village-owned enterprises (BUMDes) performance in indonesia: An exploratory study. Journal of Accounting and Investment, 20(2), 44-58 https://doi.org/10.18196/jai.2002116

Sulastriyono, \& Saputra, J. (2020). A study of supply chain management aspects of village owned enterprises in Indonesia. International Journal of Supply Chain Management, 9(3), 1221-1229. Retrieved from http://ojs.excelingtech.co.uk/index.php/IJSCM/art icle/view/5028

Suryanto, R. (2018). Peta Jalan BUMDes Sukses. Yogyakarta: PT Syncore Indonesia.
Sutrisno, S. (2019). The Feasibility of staple food business and its implication on regional food supply chain development. Journal of Socioeconomics and Development, 2(1), 54-60. https://doi.org/10.31328/jsed.v2i1.956

Wahyu, A. M., Aditya, E., Wardani, N. L., \& Jeni, S. (2019). The analysis of Putukrejo village government readiness in forming BUMDes as a development efforts of rural communities based on creative economy. International Journal of Economics, Business and Accounting Research (IJEBAR), 3(03), 270-282. https://doi.org/10.29040/ijebar.v3i03.594

Winarsi, S., Widyantoro, A., \& Moechthar, O. (2018). The law principles for village-owned enterprises (BUMDes) management in Indonesia to improve the village's economy. International Journal of Sociological Jurisprudence, 1(2), 130-136. https://doi.org/https://doi.org/10.22225/scj.1.2.7 $35.130-136$

Yan, S., \& Chen, C. (2018). The spatial transformation of traditional rural villages driven by private investment in China's developed areas: The case of Daxi Village, Anji County. Journal of Regional and City Planning, 29(2), 156-168. https://doi.org/10.5614/jrcp.2018.29.2.6 